\title{
Optogenetic Control of Subcellular Protein Location and Signaling in Vertebrate Embryos
}

\author{
Clare E. Buckley
}

\begin{abstract}
This chapter describes the use of optogenetic heterodimerization in single cells within whole-vertebrate embryos. This method allows the use of light to reversibly bind together an "anchor" protein and a "bait" protein. Proteins can therefore be directed to specific subcellular compartments, altering biological processes such as cell polarity and signaling. I detail methods for achieving transient expression of fusion proteins encoding the phytochrome heterodimerization system in early zebrafish embryos (Buckley et al., Dev Cell 36(1):117-126, 2016) and describe the imaging parameters used to achieve subcellular light patterning.
\end{abstract}

Key words Optogenetics, Heterodimerization, Zebrafish, Phytochrome, Polarity, Signaling

\section{Introduction}

Until recently, the term "optogenetics" has mostly been used to describe the rhodopsin-based control of neuronal firing. However, in the last few years there has been a rapid emergence of many different types of optogenetic systems, mainly based around lightdependent protein dimerization, clustering, or conformational change $[1,2]$. These allow researchers to use light to directly control cellular processes such as transcription [3-8], signaling activation [9-16], and full-length protein and organelle localization [17-19]. The choice of optogenetic system will depend on factors such as wavelength compatibility with imaging fluorophores, dynamic range, potential for phototoxicity, and requirements for speed of activation, reversibility, and depth of tissue to be accessed.

I describe here the plant phytochrome heterodimerization system [12], adapted for altering protein localization and signaling within zebrafish embryos in vivo at subcellular resolution [17]. Detailed methods for using this system in mammalian cells are already published [20]. The "anchor" protein phytochrome B 


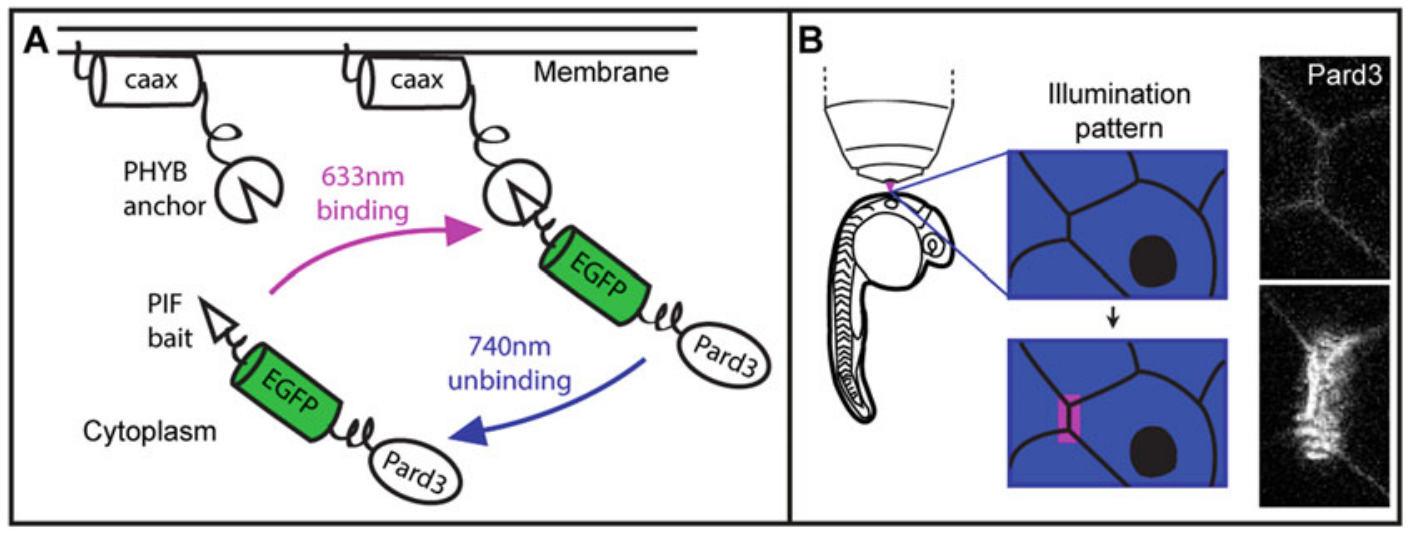

Fig. 1 Phytochrome heterodimerization. (a) In this example, the phytochrome B (PHYB) "anchor" protein is linked to the membrane moiety CAAX and the phytochrome interaction factor (PIF) "bait" protein is linked to the EGFP fluorophore and the apical polarity protein Pard3. In the presence of phycocyanobilin chromophore (PCB), PHYB heterodimerizes with PIF under $633 \mathrm{~nm}$ illumination, therefore recruiting the fusion protein Pard3EGFP-PIF6 from the cytoplasm to the membrane. After dimerization, PHYB and PIF proteins remain stably joined unless exposed to $740 \mathrm{~nm}$ light, which reverses the dimerization and sends Pard3-EGFP-PIF6 back into the cytoplasm. Both processes occur within a few seconds of light exposure. (b) "Binding" $633 \mathrm{~nm}$ light is patterned onto a subcellular region of the membrane and is overlaid by global "unbinding" $740 \mathrm{~nm}$ light. This results in the precise recruitment of Pard3-EGFP-PIF6 to the region of interest (adapted from Ref. [17] under the terms of the Creative Commons Attribution License (CC BY): http:/creativecommons.org/licenses/by/4.0/)

(PHYB) rapidly heterodimerizes with the "bait" protein phytochrome interacting factor (PIF) under "binding" far-red light (Fig. la). Red light penetrates more easily through the tissue and is less damaging than shorter wavelength light. The phytochrome system also has a large dynamic range so only very low levels of light are required to initiate binding. An important property of the system is that dimerization is stable unless actively reversed under "unbinding" near-infrared light (Fig. la), which also occurs rapidly (within a few seconds of light exposure). This means that a very high spatiotemporal resolution of optogenetic control can be achieved through the precise patterning of specific "binding" and "unbinding" wavelengths of LED or laser light (Fig. 1b). Therefore, the phytochrome system is particularly suited to experiments requiring the precise optogenetic recruitment of proteins over a long time frame within a 3D tissue, such as in vertebrate embryos. It should be noted that although potentially very powerful, the phytochrome system does require some extra experimental considerations. The high sensitivity of the system means that dimerization will also occur at shorter wavelengths. Any background dimerization can be rapidly reversed with unbinding near-infrared light but careful experimental planning is necessary. Another consideration is that the light-responsiveness of the phytochrome protein is dependent on the photoisomerization of a covalently bound phycocyanobilin (PCB) chromophore. This is not naturally produced by 
eukaryotic cells so must be added to vertebrate embryos through microinjection. This adds an additional experimental step but can be advantageous since it makes it easier to produce control embryos containing optogenetic components that are unable to dimerize. A recent paper has now demonstrated the genetic manipulation of mammalian cells to allow endogenous PCB synthesis [21]. This will hopefully be transferrable to living organisms, removing the requirement for external PCB addition in the future. Another group has developed the use of bacterial phytochromes for reversible heterodimerization under near-infrared light $[22,23]$. Although the kinetics is slower, this system does not rely on an external chromophore so is promising for future work using red-light-responsive optogenetic systems in vivo.

Although care must be taken with the use of lower wavelengthactivated optogenetic systems to avoid phototoxicity, these optogenetic methods are transferrable to vertebrate embryos and most do not require the addition of an external chromophore. Examples of in vivo applications of these techniques are given in Table $\mathrm{l}$ (this list is not exhaustive). A key difference between these approaches and the phytochrome system is that they mainly do not undergo a stable dimerization change following light illumination and instead revert to their original state in the dark usually over a few minutes (this may or may not be desirable, depending on the output of your experiment). An exception is that cobalamin-binding domain (CBD) systems can produce irreversible optical control of protein complex dissociation, depending on which receptor is being manipulated [29]. Single-cell-level optogenetic manipulation with these systems can be achieved using LED or laser light patterning (e.g., [11]), especially if the targeted tissue is superficially localized. However, if more precise spatial localization is required or the tissue is deeper within the embryo it might be necessary to use two-photon excitation to avoid background dimerization caused by light scattering within the tissue. It is important to note that the biology of the organism can also be used to maximize specificity of optogenetic dimerization. For example, expressing optogenetic components mosaically throughout the embryo will allow only a subset of cells to be activated, even under uniform illumination with binding light. Tissue-specific promoters can further refine the region within the embryo that is sensitive to optogenetic manipulation. Different "anchoring" domains can also be used to increase specificity of dimerization. In the example shown in Fig. 1, PHYB protein is "anchored" to a membrane moiety CAAX. However, "anchor" proteins can be linked to different proteins within the cell, such as motor proteins [18]. This allows the endogenous cell machinery to be hijacked to direct the localization of proteins to particular subcellular regions.

The use of optogenetic dimerization in vivo is evolving and there are many improvements currently under way as well as the 
Table 1

Examples of blue and green-light-activated optogenetic systems in vivo

\begin{tabular}{|c|c|c|}
\hline $\begin{array}{l}\text { Optogenetic } \\
\text { system }\end{array}$ & Description & In vivo examples \\
\hline $\begin{array}{l}\text { Light oxygen } \\
\text { voltage } \\
(\text { LOV) }\end{array}$ & $\begin{array}{l}\text { A flavin-binding domain interacts with a J } \alpha \\
\text { helix in the dark and unwinds in blue light. } \\
\text { LOV has been variously engineered for } \\
\text { allosteric regulation of signaling, } \\
\text { heterodimerization, and homodimerization }\end{array}$ & $\begin{array}{l}\text { Photoactivation of Racl in zebrafish } \\
\text { neutrophils [24] }\end{array}$ \\
\hline $\begin{array}{l}\text { Cryptochrome } \\
\text { (CRY2) }\end{array}$ & $\begin{array}{l}\text { Under blue light, CRY2 protein homo- } \\
\text { oligomerizes with itself and also } \\
\text { heterodimerizes with CRYPTOCHROME- } \\
\text { INTERACTING BASIC HELIX-LOOP- } \\
\text { HELIX (CIB) }\end{array}$ & $\begin{array}{l}\text { - Regulation of transcription within } \\
\text { the mouse brain using fiber-optic } \\
\text { light delivery [4] } \\
\text { - Kinase activation in whole Xenopus } \\
\text { embryos [ } 25,26] \\
\text { - Protein kinase C activation in single } \\
\text { cells within } 4-8 \text {-cell-stage early } \\
\text { mouse embryos [27] }\end{array}$ \\
\hline UVR8 & $\begin{array}{l}\text { UVR8 homodimers form in the dark and are } \\
\text { dissociated into monomers on UV exposure, } \\
\text { which can then bind CONSTITUTIVELY } \\
\text { PHOTOMORPHOGENICl (COP1) }\end{array}$ & $\begin{array}{l}\text { Control of ligand secretion in } \\
\text { zebrafish leukocytes [28] }\end{array}$ \\
\hline EL222 & $\begin{array}{l}\text { Bacterial LOV protein that binds DNA under } \\
\text { blue light }\end{array}$ & $\begin{array}{l}\text { Transcriptional control in zebrafish } \\
\text { embryos [5] }\end{array}$ \\
\hline TAEL & Modified EL222 system (less toxic) & $\begin{array}{l}\text { Transcriptional control in zebrafish } \\
\text { embryos [7] }\end{array}$ \\
\hline $\begin{array}{l}\text { Improved light- } \\
\text { inducible } \\
\text { dimer (iLID) }\end{array}$ & $\begin{array}{l}\text { Bacterial SsrA peptide within the J } \alpha \text { helix of } \\
\text { the LOV2 domain. Under blue light, iLID } \\
\text { heterodimerizes with SspB. iLID has been } \\
\text { optimized for different binding affinities }\end{array}$ & $\begin{array}{l}\text { Precise control of ERK signaling in } \\
\text { early Drosophila embryos } \\
\text { [11]. This is likely to be adaptable } \\
\text { to vertebrate embryos }\end{array}$ \\
\hline $\begin{array}{l}\text { Cobalamin- } \\
\text { binding } \\
\text { domain } \\
(\mathrm{CBD})\end{array}$ & $\begin{array}{l}\text { CBD dimerizes in the dark and dissociates into } \\
\text { monomers on green-light exposure. } \\
\text { Addition of external AdoCbl chromophore } \\
\text { is required }\end{array}$ & $\begin{array}{l}\text { Temporal control of overactive FGF } \\
\text { signaling in zebrafish [29] }\end{array}$ \\
\hline
\end{tabular}

development of new techniques. For example, expressing both components of a heterodimerization system on a single plasmid enables the relative concentrations between dimerizing proteins to be more consistent and has been found to improve the efficiency of optogenetic activation [25]. The generation of stable transgenic animal lines also produces more reproducible levels of protein expression. However, for studies in early embryos, rapid results can be generated by injecting messenger RNA encoding the separate optogenetic proteins into an individual cell during very early development (up to the 64-cell stage in zebrafish, see Note 1). Injecting at the 8-64-cell stage results in the mosaic distribution of optogenetic components throughout the embryo. Here I present methods for this simple RNA-based optogenetic approach 
using the phytochrome system. I describe how to clone plasmids, synthesize RNA, inject RNA into early embryos, mount embryos for imaging, and pattern light using a confocal laser scanning microscope.

\section{Materials}

\subsection{Plasmid Cloning (See Note 2)}

1. PSC2+ vector plasmid.

2. Restriction enzymes specific to your plasmid (e.g., ECORI and SnaBI for pCS2+ vector).

3. Electrophoresis reagents: Agarose, TAE buffer, microwave, fume hood, SYBR safe, ladder, loading dye, electrophoresis machine and tank, comb, UV transilluminator, UV protective face shield.

4. Gel extraction kit and razor blades.

5. Primers ( see Note 3): $5^{\prime}$ ends should have 30 bases overlap with the intended upstream sequence. $3^{\prime}$ ends should have a 18-25 base gene-specific sequence.

6. Template for primers (either cDNA or another plasmid containing the DNA of interest).

7. High-fidelity PCR kit.

8. PCR machine.

9. DNA purification kit and DPNl enzyme.

10. Gibson assembly solution (see Note 4).

11. Chemically competent E. coli (e.g., TOPl 0 cells).

12. Heat block containing water or water bath at $42{ }^{\circ} \mathrm{C}$.

13. Pre-warmed $\left(37^{\circ} \mathrm{C}\right) \mathrm{LB}$-agar selective plates with ampicillin.

14. LB-broth with ampicillin.

15. Miniprep and midiprep kits.

1. pCS2+ plasmid containing DNA template generated in Subheading 2.1.

2. RNase-free water (not DEPC treated).

3. NotI restriction enzyme and buffer.

4. Electrophoresis reagents (as in Subheading 2.1).

5. Sodium acetate (3 Molar).

6. Molecular biology-grade ethanol.

7. Microcentrifuge.

8. Capped RNA transcription kit for the relevant polymerase (SP6 if you are using the pCS2+ vector).

9. RNA cleanup spin column kit. 


\section{3 mRNA Injection}

1. mRNA encoding phytochrome $\mathrm{B}$ (PHYB) and phytochrome interacting factor (PIF)-tagged proteins, generated in Subheading 2.2 .

2. RNase-free water (not DEPC treated).

3. HPLC-purified PCB chromophore (protect from light): We buy this from SiChem, which is so far the only commercially available source with reliable levels of PCB purity. Dissolve this in anhydrous DMSO (see Note 5) to a stock concentration of $25 \mathrm{mM}$ and store in $5 \mu \mathrm{L}$ light-protected aliquots at $-80^{\circ} \mathrm{C}$ (see Note 6).

4. Fine loading tips.

5. Glass capillaries $(1.0 \mathrm{~mm}$ outer diameter, $0.78 \mathrm{~mm}$ inner diameter, with filament.)

6. Micropipette puller.

7. Needle-holding plate.

8. Fine-tipped watchmaker's forceps.

9. Injection plate: We use a glass slide inside a large petri dish. Alternatively, you can use an agarose mold to make agarose channels within a large petri dish.

10. Micromanipulator.

11. Microinjector and pump.

12. Graticule and mineral oil.

13. Dissecting microscope.

14. Petri dishes.

15. Aquarium water or embryo medium: Final $1 \times$ concentration is $\mathrm{NaCl}: 5 \mathrm{mM}, \mathrm{KCL}: 0.17 \mathrm{mM}, \mathrm{CaCl}_{2} \cdot 2 \mathrm{H}_{2} \mathrm{O}: 0.33 \mathrm{mM}$, $\mathrm{MgCl}_{2} \cdot 6 \mathrm{H}_{2} \mathrm{O}: 0.33 \mathrm{mM}$, HEPES free base: $5 \mathrm{mM}$.

To make up a $60 \times$ stock solution, weigh $17.53 \mathrm{~g} \mathrm{NaCl}, 0.76 \mathrm{~g}$ $\mathrm{KCl}, 2.9 \mathrm{~g} \mathrm{CaCl} \cdot 2 \mathrm{H}_{2} \mathrm{O}, 4.9 \mathrm{~g} \mathrm{MgCl}_{2} \cdot 6 \mathrm{H}_{2} \mathrm{O}$, and $71.49 \mathrm{~g}$ HEPES. Add the salts to $900 \mathrm{~mL}$ of pure water. Adjust the $\mathrm{pH}$ to 7.4 with $10 \mathrm{M} \mathrm{NaOH}$. Top up to $1 \mathrm{~L}$ with pure water and check the $\mathrm{pH}$. Filter-sterilize the stock into an autoclaved bottle. Store in the fridge. Once diluted to $1 \times$ working solution the $\mathrm{pH}$ should be approximately 7.2.

16. Aluminum foil.

17. Heat/cool incubator at $28.5^{\circ} \mathrm{C}$.

2.4 Embryo

Mounting
1. MS-222 (tricaine): Make a $25 \times$ stock solution of tricaine: Tricaine: $0.4 \% \mathrm{w} / \mathrm{v}, 1 \mathrm{M}$ Trizma base (not with HCL): $2.08 \%$. In the fume hood, weigh $4 \mathrm{~g}$ of tricaine powder into a $1 \mathrm{~L}$ glass bottle. Add $20.8 \mathrm{~mL}$ of $1 \mathrm{M}$ Trizma base (not with HCL). Add $800 \mathrm{~mL}$ pure water. Check that $\mathrm{PH}$ is 7.0 and adjust if necessary using $\mathrm{NaOH}$ or HCL. Make up to $1 \mathrm{~L}$ with pure water. 
Store in aliquots at $-20^{\circ} \mathrm{C}$. Use at a $0.016 \%$ working concentration ( $4 \mathrm{~mL}$ in $100 \mathrm{~mL}$ system water or embryo medium).

2. Fine-tipped watchmaker's forceps.

3. Low-melt agarose: Make up 1\% agarose in embryo medium (Subheading 2.3). Store in aliquots in the fridge. To melt, heat to $70{ }^{\circ} \mathrm{C}$ in heat block to melt and then cool to $50-55{ }^{\circ} \mathrm{C}$ for use.

4. Heat block.

5. Glass pipette and bulb.

6. Imaging dish.

7. Aquarium water.

8. Dissecting microscope.

9. External 740/750 nm light source (see Note 7).

2.5 Live Imaging and Optogenetic Subcellular Localization of Proteins
1. Confocal laser scanning microscope (LSM) with $633 \mathrm{~nm}$ laser line or external light patterning system containing 625 and $740 \mathrm{~nm}$ LEDs attached to either a LSM or a spinning disk microscope.

2. Dark imaging chamber with temperature control.

3. External 740/750 nm light source (see Note 7).

4. Long working distance, high numerical aperture (NA) water immersion objective ( see Note 8 ).

\section{Methods}

\subsection{Plasmid Cloning (See Note 2)}

1. Choose sequences encoding appropriate proteins to link to the PHYB "anchor" and PIF "bait." For example, if you want to activate a GTPase then choose a membrane moiety such as CAAX to link to PHYB (see Fig. la) and the relevant guanine exchange factor (GEF) to link to PIF (see Note 9).

2. Design your PHYB- and PIF-containing plasmids using gene visualizing software. Your PHYB-linked protein should either be unlabeled or be labeled with a longer wavelength fluorophore (see Note 10). The PHYB protein should only be tagged at the $3^{\prime}$ end, never at the $5^{\prime}$ end, which tends to inhibit function of the protein. You should use the shortened version of the PHYB protein (1-621 amino acids of Arabidopsis Gene ID 816394, codon optimized). Your PIF-linked protein should be labeled with a shorter wavelength fluorophore (green or blue-light responsive) to minimize background activation of the phytochrome system. PIF proteins can be tagged at either the $5^{\prime}$ or the $3^{\prime}$ end. Codon-optimized PIF6 (1-100 amino acids of Arabidopsis Gene ID 825382) or PIF3 (1-132 amino acids of Arabidopsis Gene ID 837479) can be used. 

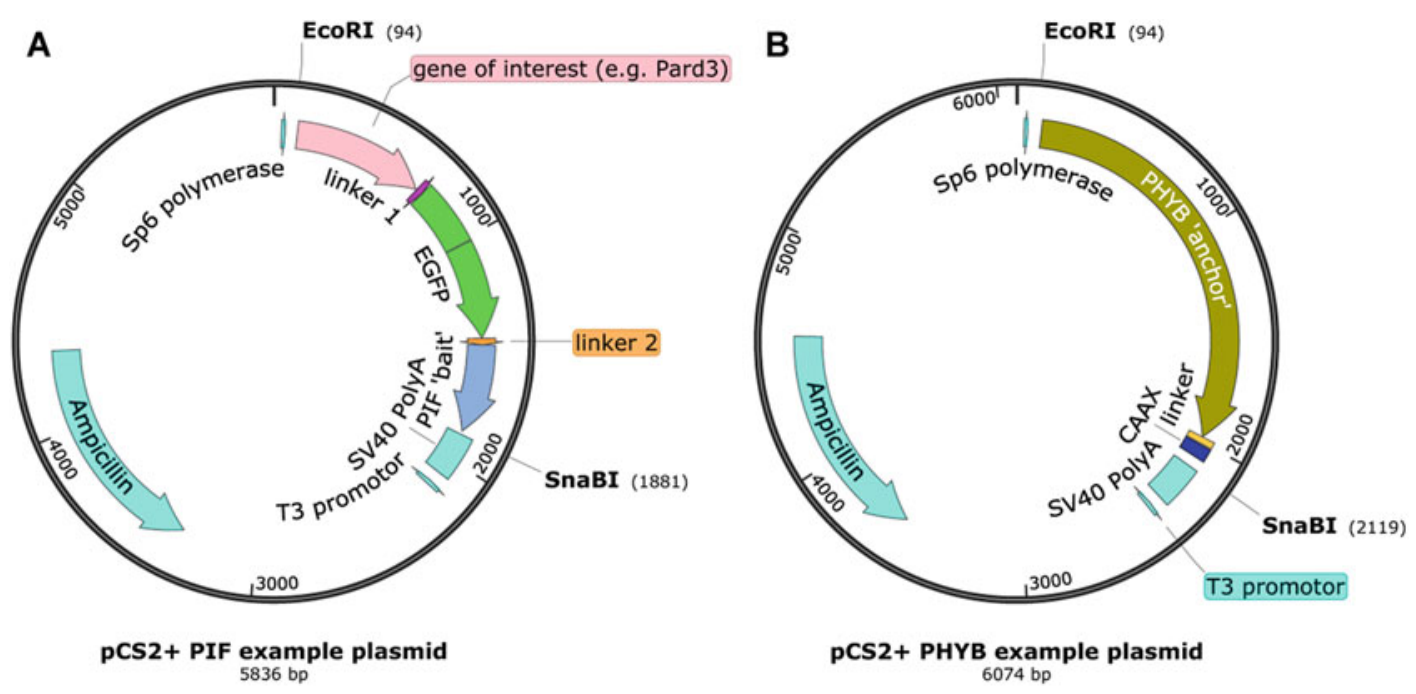

Fig. 2 Example plasmid maps. (a) PIF-linked and (b) PHYB-linked fusion proteins within the PCS2+ vector

Linkers (such as 10 amino acid polyglycine-serine) should be used between adjacent genes to allow for protein folding. Sequences for these fusion proteins should be incorporated into the pCS2 + vector plasmid between the restriction digest sites ECORI and SnaBI (Fig. 2; see Note 11).

3. If you are using Gibson assembly ( see Note 2), find templates encoding all the proteins that you want to combine into your plasmid and design and order primers to produce gene fragments with 30 base pair overlapping ends.

4. To prepare the vector (steps 4 and 5), linearize the pCS2+ vector at two distinct sites using restriction enzyme digest: Incubate $1-5 \mu \mathrm{g}$ of pCS $2+$ plasmid DNA with ECORI enzyme and buffer to a total volume of $20 \mu \mathrm{L}$ at $37^{\circ} \mathrm{C}$ for $2-3 \mathrm{~h}$ in a $1.5 \mu \mathrm{L}$ microcentrifuge tube, as per the manufacturer's instructions. Purify the linearized DNA in the tube using a DNA purification kit, as per the manufacturer's instructions. Further digest this purified DNA as above, using SnaBI enzyme and buffer.

5. Run the whole digest onto a $1 \%$ electrophoresis gel: For a $1 \%$ gel, add $1 \mathrm{~g}$ of agarose to every $100 \mathrm{~mL}$ TAE buffer and melt in the microwave. In the fume hood, add $3 \mu \mathrm{L}$ of SYBR safe and pour into the gel tank containing a comb. Leave until agarose is set. Add ladder to one well and DNA sample with the appropriate amount of gel-loading dye and water into 1-2 other wells. Run the electrophoresis machine as per the manufacturer's instructions at around $100 \mathrm{~V}$ for $20 \mathrm{~min}$. Wearing a UV protective face shield and lab coat, visualize the gel on the UV transilluminator and cut out the appropriate weight of 
band using a razor blade. Place the gel containing the band into a $1.5 \mathrm{~mL}$ microcentrifuge tube and extract the DNA using a gel extraction kit, as per the manufacturer's instructions.

6. Use the high-fidelity PCR kit to amplify your gene fragments using your primers and template DNA, as per the manufacturer's instructions ( see Note 12).

7. Remove residual template from your PCR product either by Dpnl digestion in the tube or via gel extraction, as above (see Note 13).

8. Mix together your DNA fragments in a total volume of $5 \mu \mathrm{L}$ with a molar ratio of 2:1 for insert fragment:vector backbone (see Note 14). Add this to $15 \mu \mathrm{L}$ of Gibson assembly solution and incubate at $50{ }^{\circ} \mathrm{C}$ for $1 \mathrm{~h}$.

9. Transform the Gibson assembly reaction into chemically competent cells: Thaw $50 \mu \mathrm{L}$ competent cells on ice. Still on ice, add $5 \mu \mathrm{L}$ of Gibson assembly reaction to the cells and incubate for 20-30 min. Heat shock the cells at $42{ }^{\circ} \mathrm{C}$ without shaking and then immediately transfer back to ice. Spread the cells onto two pre-warmed ampicillin-selective plates and incubate overnight at $37^{\circ} \mathrm{C}$.

10. Place the plate in the fridge in the morning. In the afternoon, pick 4-6 colonies and add each one to $4 \mathrm{~mL}$ of LB-broth containing ampicillin within a $14 \mathrm{~mL}$ Falcon tube. Shake at $37^{\circ} \mathrm{C}$ overnight.

11. Mix $750 \mu \mathrm{L}$ of each E. coli suspension with $750 \mu \mathrm{L}$ glycerol solution (50\% glycerol, $25 \%$ nuclease-free water, $25 \%$ PBS) and store at $-80^{\circ} \mathrm{C}$.

12. Extract the plasmid DNA from $1.5 \mathrm{mLs}$ of each E. coli suspension using a miniprep kit, as per the manufacturer's instructions.

13. Carry out diagnostic restriction enzyme digests on a sample of each plasmid and run on an electrophoresis gel, as above, to check that you have made the expected plasmid. Send a sample for sequencing to confirm that there are no mutations.

14. Take the glycerol stock from the miniprep with the correct sequence and scrape some frozen cells with a sterile pipette tip. Drop this tip into $2 \mathrm{~mL}$ of LB-broth in a $14 \mathrm{~mL}$ Falcon tube. Grow at $37^{\circ} \mathrm{C}$ in the shaker over the day. Add this $2 \mathrm{~mL}$ culture to $150 \mathrm{~mL}$ of $\mathrm{LB}$-broth containing ampicillin in a sterile flask and grow at $37^{\circ} \mathrm{C}$ in the shaker overnight. Extract the plasmid DNA using a midiprep kit, as per the manufacturer's instructions.

1. Linearize the DNA template at a single site using Notl restriction enzyme digest as in Subheading 3.1, step 4 ( see Note 15): 


\section{3 mRNA Injection}

2. Check that the linearization has occurred properly: Remove $1 \mu \mathrm{L}$ of digest and run on an electrophoresis gel (as in Subheading 3.1, step 5). Wearing a UV protective face shield and lab coat, visualize the gel on the UV transilluminator to determine whether you have a single band of the expected weight.

3. Ethanol precipitate the DNA (see Note 16): Add $81 \mu \mathrm{L}$ of RNase free water to make up to $100 \mu \mathrm{L}$ volume. Add $10 \mu \mathrm{L}$ of 3 molar sodium acetate and $400 \mu \mathrm{L}$ of $100 \%$ ethanol. Place at $-20{ }^{\circ} \mathrm{C}$ for at least $\mathrm{l} \mathrm{h}$. Using the microcentrifuge, spin at $14,000 \times g$ for $10 \mathrm{~min}$. Carefully remove and discard the supernatant, taking care not to remove the pelleted DNA at the bottom of the tube. Add $500 \mu \mathrm{L}$ of $70 \%$ ethanol and spin for a further $5 \mathrm{~min}$ at $14,000 \times g($ see Note 17). Carefully remove and discard the supernatant. Leave the top of the microcentrifuge open and dry the pellet at room temperature. Resuspend the DNA pellet in $6 \mu \mathrm{L}$ RNase-free water.

4. Synthesize capped mRNA using the RNA transcription kit as per the manufacturer's instructions (see Note 18).

5. Purify the RNA using an RNA cleanup spin column kit as per the manufacturer's instructions (see Note 19).

6. Store in $0.5-1 \mu \mathrm{L}$ aliquots at $-80^{\circ} \mathrm{C}($ see Note 20$)$.

1. Place a glass capillary inside the micropipette puller and adjust settings to pull an injection needle with an approximately $0.5 \mu \mathrm{m}$ tip. The specific settings will vary by individual machine (see Note 21) but an example for a Sutter P-87 machine is as follows: heat $=800$, pull $=65$, velocity $=55$, and time $=210$. Place the injection needles in a holding plate until ready to load (see Note 22).

2. Mix the PhyB- and PIF-tagged mRNA and PCB ready for injection ( see Note 23). The exact concentration of RNA will depend on what you are injecting but a rough guide is to inject approximately five times more PHYB-encoding RNA than PIF-encoding RNA (see Note 24). You should start the working concentration for $\mathrm{PCB}$ at $3 \mathrm{mM}$ and adjust it according to how much volume you are injecting and the outcome of your pilot experiments. The injection mix should ideally be used at room temperature right away.

3. Under a dissecting microscope, use forceps to line up around 20 zebrafish embryos in the injection plate and remove excess water.

4. Under low-light conditions load the RNA/PCB mix into the injection needle using a fine loading tip.

5. Insert the needle into the micromanipulator attached to a microinjector and pump. 


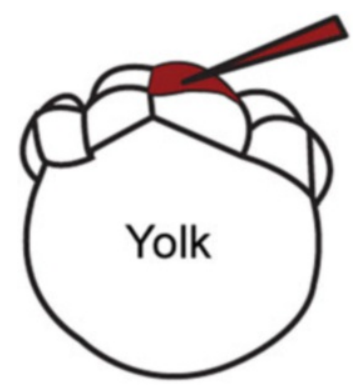

Fig. 3 RNA injection. Injecting RNA into a single cell within an 8-32-cell-stage embryo results in the mosaic distribution of fusion proteins throughout the embryo. It is possible to target expression to particular regions of the embryo to some extent. We find that targeting the central-most cells results in widespread (but not exclusive) expression in the brain

6. Use fine-tipped forceps to break the last $1-2 \mathrm{~mm}$ of the needle taper so that the tip is approximately $6 \mu \mathrm{m}$ wide.

7. Working quickly to minimize exposure to light (see Note 25), use a graticule to measure the drop size generated by the microinjector and adjust it to your required drop size (see Note 26).

8. Use the micromanipulator to insert the needle into a single cell of an 8-32-cell-stage embryo and inject a single drop into the cell (Fig. 3).

9. Place the injected embryos in embryo medium in a petri dish and wrap the dish in aluminum foil to protect it from light. Incubate at $28.5^{\circ} \mathrm{C}$ until ready for imaging.

3.4 Embryo Mounting (See Note 27)
1. When the embryos are at the right stage for imaging use finetipped forceps to remove their chorions.

2. Using a glass pipette and bulb suck up the embryo in a small amount of water.

3. Drop the embryo into the melted low-melt-point agarose at $50-55{ }^{\circ} \mathrm{C}$ ( see Note 28 ). Remove the remainder of the water in the pipette and suck up the embryo in agarose.

4. Place the embryo in a drop of agarose inside the imaging dish and orient with forceps under a dissecting microscope. Repeat with any other embryos for imaging.

5. Allow the agarose to set for around a minute and cover the embryos with embryo medium. If the embryos will be $16 \mathrm{~h}$ postfertilization (h.p.f.) or above during imaging then add tricaine to the embryo medium to prevent embryos from moving.

6. Wrap the imaging dish in aluminum foil to protect from light until imaging. 


\section{A. Confocal ROI}

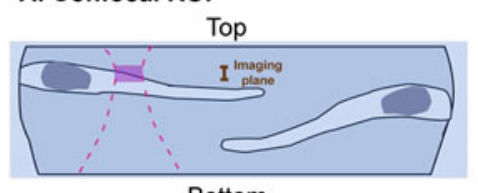

Bottom
B. DMD

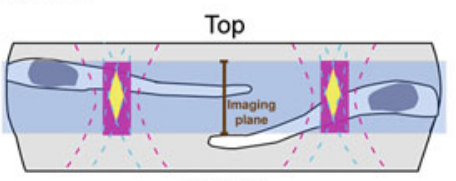

Bottom

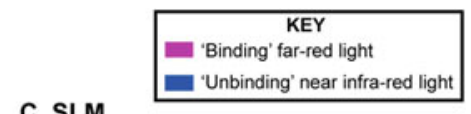

C. SLM

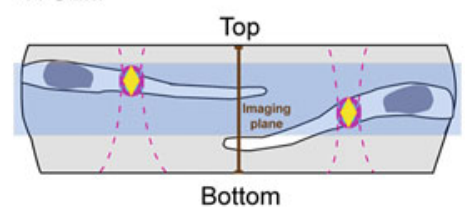

Fig. 4 Patterned light illumination. Transverse diagrams of two zebrafish neuroepithelial cells in the developing neural tube demonstrating three methods of achieving patterned light illumination. (a) Using the region of interest (ROI) function of a confocal laser scanning microscope a region of low-intensity $633 \mathrm{~nm}$ far-red laser light is patterned onto a single z-plane. This is overlaid with global $740 \mathrm{~nm}$ light from an external light source, which prevents any background heterodimerization outside this ROl that might otherwise be caused by the point-spread function pf $633 \mathrm{~nm}$ light (dotted lines). This results in a precise region of heterodimerization in xyz but optogenetics and imaging cannot occur outside this single z-level. (b) Using a digital mirror device (DMD), a specific ROl is illuminated with $625 \mathrm{~nm}$ light at a single z-plane and surrounded by an inverted pattern of $740 \mathrm{~nm}$ light. Since the pattern of binding and unbinding light is inverted it is possible to move the recruitment window to a different z-level without reversing binding, therefore allowing small z-stacks to be taken during optogenetics and imaging. However, imaging is limited to the z-planes in which patterned illumination is occurring. Due to the point-spread function of light at each z-level (dotted lines), there will be interference between the two wavelengths, meaning that the recruitment window (yellow diamond) may be smaller than the ROI. (c) Using a spatial light modulator (SLM), $633 \mathrm{~nm}$ light is directed to specific ROls over multiple z-planes, while imaging can occur at distinct z-planes. There will be interference between the two wavelengths due to the point-spread function of light at the edges of the ROI, so the recruitment window (yellow diamond) may be smaller than the Rol

\subsection{Live Imaging and Optogenetic \\ Subcellular \\ Localization \\ of Proteins (See Note \\ 29 and Figs. 4 and 5)}

1. Ensure that the dark imaging chamber on the microscope is preheated to $28.5^{\circ} \mathrm{C}$ ( see Note 30$)$.

2. Place your imaging dish onto your microscope while illuminating it with $740 / 750 \mathrm{~nm}$ light.

3. Continuing to bathe the dish in $740 / 750 \mathrm{~nm}$ light, locate the mounted embryos using $488 \mathrm{~nm}$ epifluorescence light (see Note 31).

4. Continuing to bathe the dish in $740 / 750 \mathrm{~nm}$ light and using low-intensity imaging light (488 $\mathrm{nm}$ or below, see Note 32 ), find the cells that you want to target.

5. Allow any background heterodimerization to be reversed under 740/750 nm light and then take an image (or small imaging stack) of your cells (Fig. 5b-ii). Sequentially image lower wavelengths first, followed by any red wavelengths (see Note 33).

6. Continuing to bathe the dish in $740 / 750 \mathrm{~nm}$ light, define the region of interest (ROI) in which you want heterodimerization to occur ( see Note 34).

7. Set up your imaging program to take a single image (as in step 5), followed by a period of patterned heterodimerization light only 


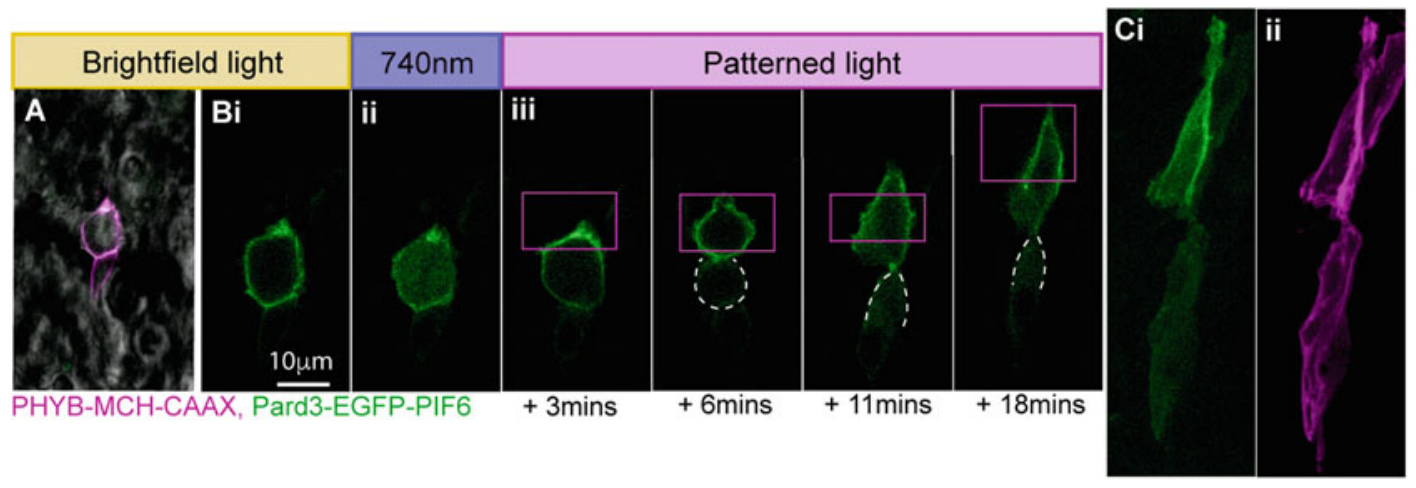

Fig. 5 Example subcellular heterodimerization image sequence. (a) Single optogenetically labeled metaphasestage cell within the zebrafish brain. (b) Image sequence of magnified cell from "A" at a single z-level, demonstrating the steps taken to achieve subcellular heterodimerization. (i) Pard3-EGFP-PIF6 was successfully recruited to the cell membrane under bright-field light. (ii) Pard3-EGFP-PIF6 was sent back into the cytoplasm under $740 \mathrm{~nm}$ light (90-s exposure). (iii) An ROI is specified (pink box) and illuminated with low-level $633 \mathrm{~nm}$ "binding" laser light while $740 \mathrm{~nm}$ "unbinding" light is present globally. This patterned light results in the recruitment of Pard3-EGFP-PIF6 to one half of the dividing cell and consequently to the asymmetric inheritance of this protein into the uppermost cell (dotted lines illustrate the location of the lower cell). This is visualized by periodic imaging under $488 \mathrm{~nm}$ light. (c) After a further 24 min of patterned light illumination at a single z-level, a $23 \mu \mathrm{m}$ z-stack was taken under 488 and $561 \mathrm{~nm}$ light to visualize the distribution of Pard3-EGFP-PIF6 (i) and PHYB-MCherry-CAAX (ii) throughout the depth of the cells (note that there is another pair of cells behind the cells of interest, with low-level Pard3-EGFP-PIF6 expression) (adapted and extended from Ref. [17] under the terms of the Creative Commons Attribution License (CC BY): http:/ creativecommons.org/licenses/by/4.0/)

(for possible approaches, see Note 29), followed by another single image. Repeat these steps for as long as necessary for your experiment (Fig. 5b-iii; see Note 35 ).

8. Following patterned light illumination you can further image your cells to assess the consequences of the protein recruitment, for example by taking a z-stack (Fig. 5c; see Note 36).

\section{Notes}

1. Depending on the protein encoded by the RNA, fusion protein expression in zebrafish usually persists for around 48 h.p.f.

2. You can use whichever method of cloning you prefer. Traditional cutting and pasting using restriction enzymes are possible but not recommended since it is slower than other methods. Some labs use Gateway cloning. We use Gibson assembly [30] in combination with restriction digest of the vector plasmid. (See this Jove article for an outline of molecular cloning: https://www.jove.com/science-education/5074/ molecular-cloning.) 
3. Standard salt purification is fine. Keep to under 60 bases total to reduce costs. Try to adhere to standard primer design guidelines (40-60\% GC content, Tm (of the $3^{\prime}$ end only) between 58 and $60{ }^{\circ} \mathrm{C},<4^{\circ} \mathrm{C}$ difference in Tm between forward and reverse primers, no identical runs of nucleotides, no more than two guanines or cytosines at the $3^{\prime}$ end). However, this will not always be possible and usually doesn't matter much.

4. You can buy the Gibson assembly solution commercially or make it yourself [30]. We make our own and freeze it at $-20{ }^{\circ} \mathrm{C}$ in $15 \mu \mathrm{L}$ aliquots in PCR tubes, ready for the Gibson assembly reaction.

5. DMSO is highly agroscopic and should be stored in a desiccator to prevent water uptake.

6. PCB seems to be very sensitive to fluctuations in temperature once it is dissolved in DMSO. It is important to ensure that it is stored in part of the freezer where the temperature will be maintained at $-80{ }^{\circ} \mathrm{C}$. You can wrap individual aliquots in aluminum foil to ensure that they are protected from light. An alternative would be to use lightproof cryotubes, which may be less sensitive to temperature fluctuations.

7. Near-infrared wavelength light sources are not found on microscopy systems as standard and it is also useful to be able to bathe embryos in "unbinding" light when mounting them before imaging. Therefore, you will probably need to source an external $740 / 750 \mathrm{~nm}$ light source. If you have access to a workshop you can buy $740 \mathrm{~nm}$ LED lights and make your own "LED board." Alternatively, you can commission filter glass for use with a white light source. We bought a heatresistant, $28 \mathrm{~mm}$ diameter, $740 \mathrm{~nm}$ band-pass filter glass from Envin Scientific Ltd., which we use to filter white light from a Schott KL 1500 light source. You can buy 740 nm LEDs (e.g., from Lightspeed Technologies) for integration into microscope systems [9]. It may be possible to buy these as external units. During imaging, you can insert a 725-750 nm long-pass filter into the bright-field light path, making sure that there are no infrared-blocking filters present $[9,20]$ or an external light patterning system can be used (see Note 29).

8. This is important to achieve high-resolution imaging throughout the depth of the embryo and to achieve precise XY region of interest (ROI) patterning.

9. It is possible to move full-length proteins using optogenetics (for example, the apical polarity protein Pard3 [17]). However, especially when manipulating cell signaling, it is better to use the minimal possible component of the pathway in order to activate endogenous pathways with minimal overexpression phenotypes. For example, the catalytic $\mathrm{DH}$ domain of the 
RhoA-specific GEF (LARG) was used to activate endogenous RhoA signaling when brought to the cell membrane [14].

10. We find that untagged PHYB “anchor" protein works more efficiently.

11. You can use either PCR to amplify all the gene fragments or a combination of restriction enzyme digests and PCR amplifications. This is what we do to avoid PCR amplifications of very long sequences. You can use different enzymes to ECORI and SnaBI as long as they produce an insertion site for your gene fragments after the SP6 polymerase promoter site and before the polyA tail.

12. To avoid introducing errors, do not use more than 25 cycles.

13. If you have used plasmid DNA as your template you can carry out a digest with Dpnl enzyme as per the manufacturer's instructions, which will destroy E. coli-methylated DNA but not the unmethylated PCR product. Otherwise you will need to run your PCR products onto a gel and extract them using the gel extraction kit.

14. Even very low concentrations of DNA often work (with lower efficiency); we have used concentrations as low as $6 \mathrm{fmol}: 3 \mathrm{fmol}$ successfully.

15. It is also possible to transcribe RNA directly from PCR templates ( see the manufacturer's instructions in the RNA synthesis kit). The resulting linearized DNA should contain the SP6 polymerase promoter site followed by the sequence to be transcribed and a polyA tail.

16. The RNA synthesis kit will have specific instructions for terminating and precipitating linearized DNA. Some recommend also using EDTA here. The protocol we have listed is an example of a method that we have used but you can adapt this accordingly.

17. Ensure that the microcentrifuge tube is oriented the same way during both spins so that the pellet stays in the same place.

18. We usually transcribe $1 \mu \mathrm{g}$ linearized DNA. It is usually recommended to assemble the transcription reaction at room temperature and to add the reaction buffer after the water and ribonucleotides are in the tube. We carry out the transcription reaction for $2 \mathrm{~h}$ before terminating the reaction with DNase.

19. Phenol-chloroform extraction and isopropanol precipitation can also be used to purify RNA as per the manufacturer's instructions in the RNA synthesis kit. This will produce purer results but is often not necessary so we use the spin column method for ease. You can run a small volume of RNA on an electrophoresis gel (as for the linearized DNA) to check that you have a clean, non-smudgy RNA band. 
20. RNA transcription kits are expensive so it is best to store RNA in small aliquots. It is better not to freeze-thaw RNA so dispose of any remaining RNA in each aliquot after use.

21. You cannot just use the same pulling settings for the different machines, even if they are the same make and model. They all pull slightly differently. You will need to adjust the settings according to the manufacturer's instructions. (See this Jove article for details on zebrafish embryo microinjection: https://www.jove.com/video/1115/microinjection-ofzebrafish-embryos-to-analyze-gene-function.)

22. We usually just place a roll of BluTac inside a large petri dish and place the side of the needles into this to make sure that the ends do not get damaged. Needles are best used right after pulling since they will be sharper and less likely to be contaminated.

23. Since PCB is dissolved in DMSO the preparation of the injection mix should be done at room temperature to prevent DMSO from freezing. Also, pipetting small volumes of DMSO is problematic so you should not try to pipette anything less than $0.5 \mu \mathrm{L}$ of PCB.

24. It is important to ensure that there are a higher number of PHYB "anchor" molecules than PIF "bait" molecules so that all PIF6 molecules can bind during heterodimerization. The balance between PHYB and PIF molecules is critical to ensure efficient heterodimerization so precise RNA injection concentration and drop size are important. We usually inject $0.5 \mathrm{~nL}$ of a mixture of $500 \mathrm{ng} / \mu \mathrm{L}$ PHYB-CAAX RNA, $70 \mathrm{ng} / \mu \mathrm{L}$ PIF6EGFP RNA, and 3mM PCB, diluted in RNase-free water.

25. Until the PCB has covalently bound to the PHYB protein it is unstable under light. Therefore, ideally injections should be done in a darkroom with the microscope bright-field light on a dim setting. You can minimize light exposure by injecting batches of embryos with new injection mix. Do not inject for more than a few minutes each time.

26. A drop size of $0.5 \mathrm{~nL}$ is appropriate for injecting one cell in an eight-cell-stage embryo. Smaller drop sizes may be required for older embryos. It is worth setting up the injecting settings to approximately the right settings using water injected into mineral oil so that you can spend less time adjusting these settings for your light-sensitive injection mix.

27. The phytochrome system is very sensitive so heterodimerization will occur if embryos are exposed to white light. This heterodimerization is reversed under $740 / 750 \mathrm{~nm}$ light so an external $740 / 750 \mathrm{~nm}$ light source can be used during mounting to reduce background heterodimerization. It is also 
possible to mount embryos using $488 \mathrm{~nm}$ epifluorescence if it is particularly important to avoid background binding.

28. It is better to keep the agarose temperature as low as possible to reduce damage to the embryos but note that the lower the temperature, the faster the agarose will set during mounting.

29. If you have access to a confocal laser scanning microscope with a $633 \mathrm{~nm}$ laser line it is possible to adapt already existing imaging systems to achieve good subcellular recruitment at a particular Z-plane by using a ROI of low-intensity $633 \mathrm{~nm}$ laser light (approximately 1\%) overlaid with a global $740 / 750 \mathrm{~nm}$ unbinding light from an external light source (see Figs. $1 \mathrm{~b}$ and 5). This was the method used in Buckley et al., 2016. The global $740 / 750 \mathrm{~nm}$ unbinding light will reverse any potential background heterodimerization caused by the point spread function of the $633 \mathrm{~nm}$ laser at other z-planes. However, this method requires that the levels of binding and unbinding light be adjusted so that the binding light outcompetes the unbinding light at the region of interest. Also, recruitment is limited to a single $\mathrm{z}$-plane since moving the recruitment window to a different $z$-plane would result in the global $740 / 750 \mathrm{~nm}$ unbinding light reversing binding in the original z-plane (see Fig. 4a).

An alternative approach would be to use an inverted light pattern (i.e., only binding far-red light in the region of interest and only unbinding near-infrared light everywhere else). For this you need a separate light patterning system. One option is to use a digital mirror device (DMD), which allows the use of an array of micromirrors to precisely focus light in particular $2 \mathrm{D}$ patterns. Inverted light patterning using DMDs has been used very effectively for the phytochrome system in cell culture [9]. This approach is still limited to light patterning at single $\mathrm{z}$-planes, but small $\mathrm{z}$-stacks could be taken to achieve recruitment over a 3D area (see Fig. 4b).

Another option is to use a spatial light modulator (SLM) to alter the phase of coherent light, thereby shaping the excitation in $3 \mathrm{D}$. By using a second objective, the imaging plane can be decoupled from the light patterning plane. Also, several different regions of interest can be simultaneously patterned over different z-planes (see Fig. 4c). Precise Z-resolution of patterned light can be achieved through the use of two-photon excitation, such as for the cryptochrome system in Drosophila [10]. However, it is still unclear whether the longer wavelengths used by two-photon microscopes are compatible with the red-light-responsive phytochrome system.

30. It is important to use a dark imaging chamber, to prevent background light from reaching the sample. 
31. Since you can reverse any background heterodimerization using the $740 / 750 \mathrm{~nm}$ light it may not be important to your experiment to avoid background activity of the phytochrome system before imaging. In that case, you can just set up the imaging under bright-field illumination, which will be easier. When using an RNA-based optogenetic approach there will be some heterogeneity in expression between cells, meaning that in some cells optimal heterodimerization may not occur (because the balance of PHYB and PIF molecules is not optimal). By allowing background heterodimerization you can screen embryos and cells that respond optimally by selecting those in which your protein of interest has already been recruited (e.g., to the membrane, Fig. 5b-i).

32. The high sensitivity of the phytochrome system means that background heterodimerization will occur, even under $488 \mathrm{~nm}$ light. This is minimal if laser levels are kept low and $740 / 750 \mathrm{~nm}$ background light is maintained. Less background activation will occur if lower wavelength fluorophores are used for imaging (such as BFP).

33. This is to ensure that any transient background heterodimerization caused by illumination to longer wavelength light does not confuse the signal from your protein of interest.

34. See introduction where we discuss how the biology of the system can be used to further refine the specificity of optogenetic binding, reducing the need for precise light patterning.

35 . Ideally the patterned binding/unbinding light should be constantly present and this should be overlaid by periodic imaging at the imaging wavelengths (Fig. 5b-iii). If heterodimerization is occurring optimally, binding between "anchor" and "bait" molecules should be visible within a few seconds. You will need to adjust the time interval between images according to your own pilot experiments. Imaging every minute is a good starting point. You will also need to adjust the location of the ROI as the cells move and grow.

36. As mentioned, background heterodimerization will occur under imaging light, especially when using red wavelengths. Therefore, the type of further imaging that can be carried out following heterodimerization will depend on the setup of your experiment. You could bathe the embryo in global $740 / 750 \mathrm{~nm}$ "unbinding" light and periodically image the location of your protein of interest. This would allow you to assess the consequences of a short-term heterodimerization later in development. However, if you require the persistent subcellular localization of a protein then you will need to continue to illuminate the cells with patterned light (as in Subheading 3.5, step 7) until the end of your experiment. 
However, if the spatial localization of heterodimerization is determined by the location of the anchor protein, rather than by your spatial light patterning (as discussed in the introduction) then there is no need for the unbinding $740 / 750 \mathrm{~nm}$ light and you can simply carry out a normal time-lapse image of your cells, ensuring that the embryo is illuminated with red light to maximize heterodimerization.

\section{References}

1. Tischer D, Weiner OD (2014) Illuminating cell signalling with optogenetic tools. Nat Rev Mol Cell Biol 15(8):551-558. https://doi.org/10. $1038 / \mathrm{nrm} 3837$

2. Rost BR, Schneider-Warme F, Schmitz D, Hegemann P (2017) Optogenetic tools for subcellular applications in neuroscience. Neuron 96(3):572-603. https://doi.org/10. 1016/j.neuron.2017.09.047

3. Kennedy MJ, Hughes RM, Peteya LA, Schwartz JW, Ehlers MD, Tucker CL (2010) Rapid blue-light-mediated induction of protein interactions in living cells. Nat Methods 7 (12):973-975. https://doi.org/10.1038/ nmeth. 1524

4. Konermann S, Brigham MD, Trevino A, Hsu PD, Heidenreich M, Cong L et al (2013) Optical control of mammalian endogenous transcription and epigenetic states. Nature 46:1-17. https://doi.org/10.1038/ nature 12466

5. Motta-Mena LB, Reade A, Mallory MJ, Glantz S, Weiner OD, Lynch KW et al (2014) An optogenetic gene expression system with rapid activation and deactivation kinetics. Nat Chem Biol 10(3):196-202. https://doi.org/ $10.1038 /$ nchembio. 1430

6. Pathak GP, Spiltoir JI, Hoglund C, Polstein LR, Heine-Koskinen S, Gersbach CA et al (2017) Bidirectional approaches for optogenetic regulation of gene expression in mammalian cells using Arabidopsis cryptochrome 2. Nucleic Acids Res 45(20):el67. https:// doi.org/10.1093/nar/gkx260

7. Reade A, Motta-Mena LB, Gardner KH, Stainier DY, Weiner OD, Woo S (2016) TAEL: A zebrafish-optimized optogenetic gene expression system with fine spatial and temporal control. Development 144(2):345-355. https:// doi.org/10.1242/dev.139238

8. Wu YI, Frey D, Lungu OI, Jaehrig A, Schlichting I, Kuhlman B et al (2009) A genetically encoded photoactivatable Rac controls the motility of living cells. Nature 461
(7260):104-108. https://doi.org/10.1038/ nature 08241

9. Graziano BR, Gong D, Anderson KE, Pipathsouk A, Goldberg AR, Weiner OD (2017) A module for Rac temporal signal integration revealed with optogenetics. J Cell Biol 216(8):2515-2531. $1083 /$ jcb.201604113

10. Guglielmi G, Barry JD, Huber W, De Renzis S (2015) An optogenetic method to modulate cell contractility during tissue morphogenesis. Dev Cell 35(5):646-660. https://doi.org/10. 1016/j.devcel.2015.10.020

11. Johnson HE, Goyal Y, Pannucci NL, Schüpbach T, Shvartsman SY, Toettcher JE (2017) The spatiotemporal limits of developmental erk signaling. Dev Cell 40(2):185-192. https://doi.org/10.1016/j.devcel.2016.12. 002

12. Levskaya A, Weiner OD, Lim WA, Voigt CA (2009) Spatiotemporal control of cell signalling using a light-switchable protein interaction. Nature 461(7266):997-1001. https:// doi.org/10.1038/nature08446

13. Toettcher JE, Weiner OD, Lim WA (2013) Using optogenetics to interrogate the dynamic control of signal transmission by the Ras/Erk module. Cell 155(6):1422-1434. https://doi. org/10.1016/j.cell.2013.11.004

14. Wagner E, Glotzer M (2016) Local RhoA activation induces cytokinetic furrows independent of spindle position and cell cycle stage. J Cell Biol 213(6):641-649. https://doi.org/ $10.1083 /$ jcb.201603025

15. Wilson MZ, Ravindran PT, Lim WA, Toettcher JE (2017) Tracing information flow from Erk to target gene induction reveals mechanisms of dynamic and combinatorial control. Mol Cell 67(5):757-769.e5. https://doi.org/10. 1016/j.molcel.2017.07.016

16. Yang X, Jost APT, Weiner OD, Tang C (2013) A light-inducible organelle-targeting system for dynamically activating and inactivating signaling in budding yeast. Mol Biol Cell 24 
(15):2419-2430. https://doi.org/10.1091/ mbc.E13-03-0126

17. Buckley CE, Moore RE, Reade A, Goldberg AR, Weiner OD, Clarke JDW (2016) Reversible optogenetic control of subcellular protein localization in a live vertebrate embryo. Dev Cell 36(1):117-126. https://doi.org/10. 1016/j.devcel.2015.12.011

18. van Bergeijk P, Adrian M, Hoogenraad CC, Kapitein LC (2015) Optogenetic control of organelle transport and positioning. Nature 518:111-114. https://doi.org/10.1038/ nature 14128

19. Adrian M, Nijenhuis W, Hoogstraaten RI, Willems J, Kapitein LC (2017) A phytochrome-derived photoswitch for intracellular transport. ACS Synth Biol 6 (7):1248-1256. https://doi.org/10.1021/ acssynbio.6b00333

20. Toettcher JE, Gong D, Lim WA, Weiner OD (2011) Light control of plasma membrane recruitment using the Phy-PIF system. Methods Enzymol 497. Elsevier:409-423. https:// doi.org/10.1016/B978-0-12-385075-1. 00017-2

21. Uda Y, Goto Y, Oda S, Kohchi T, Matsuda M, Aoki K (2017) Efficient synthesis of phycocyanobilin in mammalian cells for optogenetic control of cell signaling. Proc Natl Acad Sci U S A 114(45):11962-11967. https://doi.org/ 10.1073 /pnas.1707190114

22. Kaberniuk AA, Shemetov AA, Verkhusha VV (2016) A bacterial phytochrome-based optogenetic system controllable with near-infrared light. Nat Methods 13(7):591-597. https:// doi.org/10.1038/nmeth.3864

23. Redchuk TA, Omelina ES, Chernov KG, Verkhusha VV (2017) Near-infrared optogenetic pair for protein regulation and spectral multiplexing. Nat Chem Biol 13(6):633-639. https://doi.org/10.1038/nchembio.2343
24. Yoo SK, Deng Q, Cavnar PJ, Wu YI, Hahn KM, Huttenlocher A (2010) Differential regulation of protrusion and polarity by PI3K during neutrophil motility in live zebrafish. Dev Cell 18(2):226-236. https://doi.org/10. 1016/j.devcel.2009.11.015

25. Krishnamurthy VV, Khamo JS, Mei W, Turgeon AJ, Ashraf HM, Mondal P et al (2016) Reversible optogenetic control of kinase activity during differentiation and embryonic development. Development 143(21):4085-4094. https://doi.org/10.1242/dev.140889

26. Krishnamurthy VV, Turgeon AJ, Khamo JS, Mondal P, Sharum SR, Mei W et al (2017) Light-mediated reversible modulation of the mitogen-activated protein kinase pathway during cell differentiation and xenopus embryonic development. J Vis Exp. (124). https://doi. org/10.3791/55823

27. Zhu M, Leung CY, Shahbazi MN, ZernickaGoetz M (2017) Actomyosin polarisation through PLC-PKC triggers symmetry breaking of the mouse embryo. Nat Commun 8(1):921. https://doi.org/10.1038/s41467-01700977-8

28. Sarris M, Olekhnovitch R, Bousso P (2016) Manipulating leukocyte interactions in vivo through optogenetic chemokine release. Blood 127(23):e35-e41. https://doi.org/10. 1182/blood-2015-11-684852

29. Kainrath S, Stadler M, Reichhart E, Distel M, Janovjak H (2017) Green-light-induced inactivation of receptor signaling using cobalaminbinding domains. Angew Chem Int Ed Engl 56 (16):4608-4611. https://doi.org/10.1002/ anie.201611998

30. Gibson DG, Young L, Chuang RY, Venter JC, Hutchison CA 3rd, Smith HO (2009) Enzymatic assembly of DNA molecules up to several hundred kilobases. Nat Methods 6 (5):343-345. https://doi.org/10.1038/ nmeth.1318

Open Access This chapter is licensed under the terms of the Creative Commons Attribution 4.0 International License (http://creativecommons.org/licenses/by/4.0/), which permits use, sharing, adaptation, distribution and reproduction in any medium or format, as long as you give appropriate credit to the original author(s) and the source, provide a link to the Creative Commons license and indicate if changes were made.

The images or other third party material in this chapter are included in the chapter's Creative Commons license, unless indicated otherwise in a credit line to the material. If material is not included in the chapter's Creative Commons license and your intended use is not permitted by statutory regulation or exceeds the permitted use, you will need to obtain permission directly from the copyright holder. 